\title{
RESPONSE TO WATER DEFICIT OF Ipomoea cairica (L.) SWEET
}

\author{
Resposta de Ipomoea cairica (L.) Sweet à deficiência hídrica
}

\author{
Grasiela Bruzamarello Tognon¹, Cláudia Petry², Francine Lorena Cuquel ${ }^{3}$
}

\begin{abstract}
Green spaces require frequent watering, increasing the pressure on water resources. The use of native plants in landscaping reduces the risks of biological contamination, contributing to preservation of Brazilian biodiversity and provides the value of sustainability in urban green areas. Of these native plants, a restricted number are native lianas which are adapted to Brazilian climate and available on the market. In this regard, the selection and recommending of native plants which are efficient in use of water for planting in urban areas constitute an effective strategy for conservation of water resources. Thus, the purpose of this study was to evaluate the growth and development of I. cairica plants submitted to water deficit. For a period of 100 days after transplanting, plants of this species were grown with watered at pot capacity except for 30 days (from the $30^{\text {th }}$ to the $60^{\text {th }}$ day) when four water deficits $(25,50,75$ and $100 \%$ pot capacity) were applied. During all regimes of water deficiency applied, there was a $100 \%$ survival rate. After reestablishment of water regime the species recovered its growth, even that was submitted to the $25 \%$ of pot capacity. It testify that $I$. cairica is resistant to low water availability.
\end{abstract}

Index terms: Morning glory, climbing plants, water stress, landscaping.

\section{RESUMO}

Os espaços verdes necessitam de irrigações freqüentes, aumentando a pressão sobre os recursos hídricos. A utilização de plantas nativas em paisagismo diminui os riscos de contaminação biológica, contribui para a preservação da biodiversidade brasileira e propicia a sua valorização sustentável em áreas verdes. Destas, um número restrito são de lianas nativas aclimatadas e disponíveis no mercado. Nesse sentido, a seleção e indicação de plantas nativas eficientes no uso da água para implantação em paisagismo constituem-se uma estratégia eficaz na conservação dos recursos hídricos. Assim, buscou-se avaliar o crescimento e desenvolvimento de plantas de Ipomoea cairica submetidas a déficit hídrico. Ao longo de 100 dias após o transplante, plantas dessa espécie foram cultivadas com irrigação em capacidade de vaso, exceto por 30 dias (do $31^{\circ}$ ao $60^{\circ}$ dia) quando se aplicou quatro regimes hídricos ( 25 , 50,75 e 100\% de capacidade de vaso). Durante o período de deficiência hídrica, houve $100 \%$ de sobrevivência, em todos os regimes hídricos aplicados. Após o restabelecimento hídrico, a espécie retomou seu crescimento, mesmo a que foi submetida a $25 \%$ da capacidade de vaso. Isto prova que $I$. cairica é resistente a baixa disponibilidade hídrica.

Termos para indexação: Ipoméia, trepadeiras, estresse hídrico, paisagismo.

\section{(Received in march 8, 2012 and approved in may 30, 2012)}

\section{INTRODUCTION}

Climbing plants are important for gardens, because they may be used in beautifying walls, frontages, pergolas and arbors (PAIVA, 2008). The number of native plants available on the market for this purpose is quite small, mainly due to the lack of research (BARROSO et al., 2007). In the Brazilian floriculture market, only some native species are available, such as: Allamanda cathartica, Philodendron hederaceum, Cuspidaria convoluta, Pyrostegia venusta, Combretum fruticosum, Turbina corymbosa, Bougainvillea spectabilis and B. glabra (LORENZI; SOUZA, 2001).

Due to anthropic pressure, many native species run the risk of extinction (CUQUEL et al., 2009). The growing of native plants is a manner of preservation of these species (LEAL; BIONDI, 2006). In addition, the use of native plants for ornamentation reduces the risks of biological contamination by exotic species (BARROSO et al., 2007) and contributes to preservation of biodiversity and sustainable use of green areas (YOUNIS et al., 2010).

For maintenance of urban landscaping, frequent watering is performed which raises the cost and does not collaborate with sustainable use of water resources. Due to the capacity of native species for adaptation to diverse environmental conditions (FRANCO et al., 2006), including low water availability (HITCHMOUGH, 2010), has recommended the use of these plants in landscaping. For that reason, the use of native species with ornamental potential is a trend in contemporary landscaping (HEIDEN et al., 2006; BRETZEL; PEZZAROSSA, 2010). Thus, studies

1Universidade Federal do Paraná/UFPR - Rua dos Funcionários - 1540 - Juvevê - Cx. P. 19061 - 80035-050 - Curitiba-PR - Brasil - gbtbio@gmail.com 2Universidade de Passo Fundo/UPF - Faculdade de Agronomia e Medicina Veterinária/FAMV - Passo Fundo - RS - Brasil

${ }^{3}$ Universidade Federal do Paraná/UFPR - Departamento de Fitotecnia e Fitossanitarismo - Curitiba - PR - Brasil 
on drought tolerance, based on physiological parameters related to the state of water in the plant, may assist in the selection of the right plants for use in gardens (CHYLIŃSKI et al., 2007).

The species I. cairica or morning glory is a climbing, herbaceous, branched plant with exuberant lilac-colored flowers, and may be used as an ornamental plant (LORENZI; SOUZA, 2001). It is native from Brazil and is found in various types of environments: open fields, vacant lots, edges of forested areas and roadsides (FERREIRA; MIOTTO, 2009). The purpose of this study was to evaluate the growth and development of $I$. cairica plants submitted to water deficit.

\section{MATERIAL AND METHODS}

The experiment was carried out in the North Region of the state of Rio Grande do Sul, Brazil, at $28^{\circ} 15^{\prime} \mathrm{S}$ and $52^{\circ} 24^{\prime} \mathrm{W}$, altitude of $687 \mathrm{~m}$. I. cairica seedlings were transplanted to $3 \mathrm{~kg}$ plastic pots, containing four basal holes, filled with a substrate composed by Oxisol, mixed with organic compost at the ratio of $2: 1(\mathrm{v}: \mathrm{v})(\mathrm{pH}: 6.5, \mathrm{P}:>$ $50 \mathrm{mg} / \mathrm{dm}^{3}, \mathrm{~K}: 927 \mathrm{mg} / \mathrm{dm}^{3}, \mathrm{Ca}: 4.9 \mathrm{cmol}_{\mathrm{c}} / \mathrm{dm}^{3}, \mathrm{Mg}: 5.0 \mathrm{cmol} /$ $\mathrm{dm}^{3}$, CTC: $14.5 \mathrm{cmol} / \mathrm{dm}^{3}, \mathrm{~S}: 36 \mathrm{mg} / \mathrm{dm}^{3}, \mathrm{~B}: 10 \mathrm{mg} / \mathrm{dm}^{3}, \mathrm{Mg}$ : $5 \mathrm{mg} / \mathrm{dm}^{3}, \mathrm{Zn}: 77 \mathrm{mg} / \mathrm{dm}^{3}, \mathrm{Cu}: 1.4 \mathrm{mg} / \mathrm{dm}^{3}$, clay: $35 \%$, organic matter: $4.8 \%$, porosity total: $0.673 \mathrm{~m}^{3} / \mathrm{m}^{3}$; aeration porosity: $0.369 \mathrm{~m}^{3} / \mathrm{m}^{3}$, and water availability: $0.110 \mathrm{~m}^{3} / \mathrm{m}^{3}$ ).

Pot capacity (PC) was determined according to the methodology proposed by Sinclair et al. (2005). During the first 29 days after transplant all pots were watered with $100 \%$ PC. From 30 to 60 days after transplant pots were submitted to the water regimes of $25 \%, 50 \%, 75 \%$ and $100 \%$ PC. From 61 to 100 days after transplant pots were watered with $100 \%$ PC. Watering was manual on a daily basis, and under the highest water amount supplied no water drained.

Water deficit were evaluated from 30 to 60 days after transplant by measuring fresh mass and dry mass of leaves, stems and roots. Water mass (WM) all these structures were calculated by the difference of the fresh mass and dry mass. Throughout the 100 days of this study number of leaves and branches per plant; and length of the largest branch were evaluated. The water relations (WR), water status (WS) and water deficit (WD) were obtained by the methodology of Cruiziat and Bodet (1974) modified by Petry (1992):

Water status (WS) of each organ, regarded as a qualitative type (water content in relation to dry mass): $\mathrm{WS}=$ dry mass - fresh mass / fresh mass $(\mathrm{g} / \mathrm{g})$.

Water deficit (WD):

$$
\mathrm{D}=\frac{\mathrm{WM}_{\mathrm{t}}}{\mathrm{WM}_{\mathrm{t}}}-\mathrm{WM}_{\text {def }}=\frac{\Delta \mathrm{WM}}{\mathrm{WM}_{\mathrm{t}}}
$$

Where $\mathrm{WM}_{\mathrm{t}}$ is the water mass in the organ in full turgescence, $\mathrm{WM}_{\text {def }}$ is the water mass in the organ in deficit, and $\triangle \mathrm{WM}$ is the variation of water mass in the organ.

Tolerance indexes $\left(\mathrm{I}_{\mathrm{T}}\right)$ were obtained by the relation of dry mass production and physiological and morphological determinations of the treatments under stress in relation to the results of the control $\left(\mathrm{I}_{t}=\right.$ Productivity in 75,50 and $25 \%$ of $\mathrm{PC} /$ productivity in $100 \%$ of PC x 100) (VIDAL; ARNOUX, 1981).

Plants were grown inside a greenhouse with curved ceiling covered with low density polyethylene (LDPE) of $150 \mu \mathrm{m}$ arranged externally at a height of $2.5 \mathrm{~m}$, and a black shading screen, with $75 \%$ shade index. Temperature was measured by using a thermometer installed inside the greenhouse. The maximum daily temperatures were between 22 and $34^{\circ} \mathrm{C}$, and minimum daily were between 9 and $21^{\circ} \mathrm{C}$.

Experimental design was completely randomized with four water regimes $(25 \%, 50 \%, 75 \%$ and $100 \%$ PC), with nine replications of each water regimes, evaluated from 30 to 60 days after transplant. Data were submitted to analysis of variance with posterior regression analysis through the statistical program SISVAR (FERREIRA, 2011).

\section{RESULTS AND DISCUSSION}

For WS, water storage capacity in the different plant organs showed differential behavior among the organs and the water deficits (Figure 1). Leaves WS was greater in the $100 \%$ PC treatment, followed by the treatments of 50, 75 and $25 \%$ PC. The greatest WS for the stem was observed in the $75 \%$ treatment. The root was the organ that exhibited the greatest WS for the $25 \%$ treatment $(8.1 \mathrm{~g} / \mathrm{g})$. According to Sinclair et al. (2005) water reserves in the different plant organs may vary for the same water situation in a different way among species and even among cultivars. The study of the WS dynamic of the plant is complex and involves metabolic interactions, but the tendency upon applying the deficit is to reduce the water status, and if the species or cultivar is more tolerant, there are increases in its water status (CRUZIAT; BODET, 1974; PETRY, 1992). Increase in the WS of the plants found in I. cairica during the study, showed this specie is tolerant to water stress.

Upon analyzing the WD there was an increase in water deficit in the leaves and decrease in the roots, showing that the plant stored more water in the roots during the stress period (Table 1). After water reestablishment, the plants inverted the response, with 
greater water deficit in the leaves and less in the roots. Plants capable of tolerating periods of water deficit are those that make frugal use of water, conserving part in the soil and making osmotic adjustment, reducing water potential and turgor pressure in the leaves (FRANCO et al., 2006; TAIZ; ZEIGER, 2009).

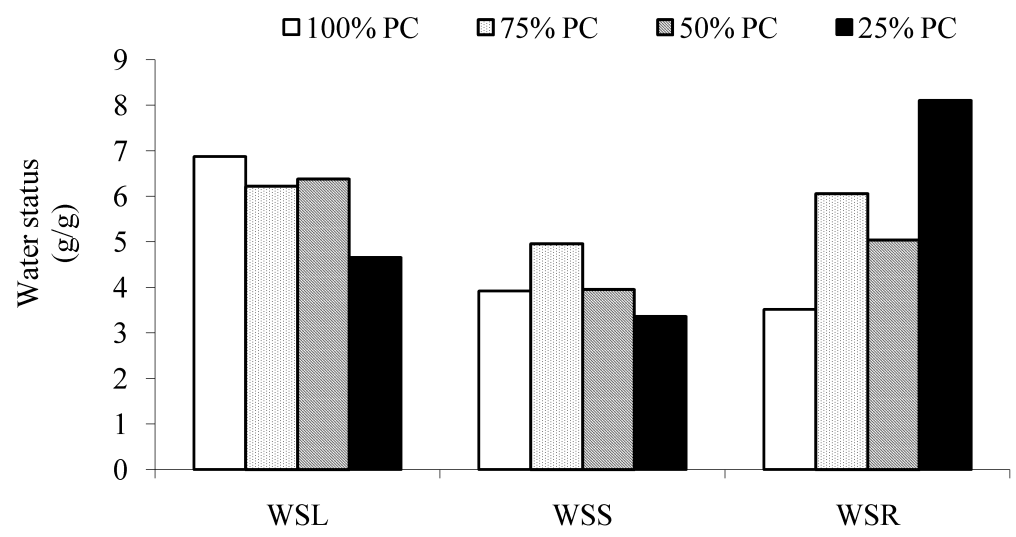

Figure 1 - Water status of the leaves (WSL), water status of the stems (WSS) and water status of the roots (WSR) during the application of different water deficits $(25,50,75$ and $100 \%$ of pot capacity (PC) from 30 to 60 days after transplant.

Table 1 - Water deficit (\%) in relation to the control and tolerance indexes for the physiological parameters in each plant organ of Ipomoea cairica during (30-60 days) and after (61-100 days) application of the different water.

\begin{tabular}{|c|c|c|c|c|c|c|}
\hline & \multicolumn{3}{|c|}{$\begin{array}{l}\text { Water stress period } \\
\text { (30-60 days })\end{array}$} & \multicolumn{3}{|c|}{$\begin{array}{l}\text { Post water stress period } \\
\quad(61-100 \text { days })\end{array}$} \\
\hline & $75 \% \mathrm{PC}$ & $50 \% \mathrm{PC}$ & $25 \% \mathrm{PC}$ & $75 \% \mathrm{PC}$ & $50 \% \mathrm{PC}$ & $25 \% \mathrm{PC}$ \\
\hline \multicolumn{7}{|l|}{ Water deficit } \\
\hline D Total above ground part & 32.5 & 27.8 & 72.4 & 3.3 & 10.6 & 31.8 \\
\hline D Leaves & 49.4 & 42.2 & 81.7 & 1.7 & 4.6 & 37.5 \\
\hline D Stems & 13.3 & 11.4 & 6.19 & 4.7 & 16.1 & 26.6 \\
\hline D Roots & 19.1 & 37.8 & 55.1 & -19.9 & -47.5 & -11.0 \\
\hline \multicolumn{7}{|l|}{ Physiological Parameters } \\
\hline $\mathrm{I}_{\mathrm{T}}$ Consumption & 78.24 & 55.42 & 16.51 & 98.36 & 105.53 & 94.73 \\
\hline \multicolumn{7}{|l|}{ Dry mass } \\
\hline $\mathrm{I}_{\mathrm{T}}$ Leaves & 50.97 & 58.40 & 19.04 & 97.82 & 100.38 & 64.94 \\
\hline $\mathrm{I}_{\mathrm{T}}$ Stems & 83.58 & 88.94 & 40.89 & 97.80 & 88.0 & 74.24 \\
\hline $\mathrm{I}_{\mathrm{T}}$ Roots & 72.46 & 57.96 & 38.67 & 127.08 & 154.17 & 89.89 \\
\hline \multicolumn{7}{|l|}{ Water mass } \\
\hline $\mathrm{I}_{\mathrm{T}}$ Leaves & 50.55 & 57.77 & 18.27 & 98.19 & 95.37 & 62.42 \\
\hline $\mathrm{I}_{\mathrm{T}}$ Stems & 88.67 & 90.66 & 38.95 & 95.22 & 83.84 & 73.37 \\
\hline $\mathrm{I}_{\mathrm{T}}$ Roots & 80.81 & 62.14 & 44.87 & 119.97 & 147.57 & 88.98 \\
\hline \multicolumn{7}{|l|}{ Water status } \\
\hline $\mathrm{I}_{\mathrm{T}}$ Leaves & 90.39 & 92.86 & 67.68 & 100 & 94.28 & 76.19 \\
\hline $\mathrm{I}_{\mathrm{T}}$ Stems & 126.27 & 100.76 & 85.71 & 87.55 & 82.25 & 96.08 \\
\hline $\mathrm{I}_{\mathrm{T}}$ Roots & 172.6 & 143.30 & 230.76 & 73.71 & 86.09 & 91.42 \\
\hline
\end{tabular}

Ciênc. agrotec., Lavras, v. 36, n. 3, p. 318-324, maio/jun., 2012 
Upon establishing the tolerance indexes $\left(\mathrm{I}_{\mathrm{T}}\right)$ (Table 1) it was observed that to the extent that water restriction increases, the tendency was for reduction in the quantity of water in the leaves and increase in the roots. The $\mathrm{I}_{\mathrm{T}}$ of consumption also decreased in accordance with the water deficit. With $25 \%$ of PC, the plants consumed less; however, upon returning to the normal water deficit, they resumed normal consumption. Increase in water deficit in the leaves of I. cairica during the period of stress proves this characteristic of drought tolerance. These characteristics are also present in other ornamental species considered resistant to drought periods, such as Penstemon barbatus, Penstemon x mexicali and Lavandula angustifolia (ZOLLINGER et al., 2006), and which are recommended for use in landscaping.

The different water deficit applied from 30 to 60 days after transplant did not affect the number of shoots. Reduction in the water level of the substrate from $100 \%$ to $25 \%$ of PC caused a decrease in the length of the shoots
(Figure 2). One of the first responses to water stress is reduction in plant growth (YIN et al., 2005). In studies with two varieties of $I$. batatas, water stress proved to have a significant effect on growth of the above ground part of the plants (VAN HEERDEN; LAURIE, 2008). Carvalho et al. (2003) also observed less height in Artemisia plants maintained at a low water level. For other ornamental species, like Impatiens walleriana, Petunia $\mathrm{x}$ hybrida and Pelargonium hortorum, water stress proved to be a decisive factor for growth (CHYLINSSKI et al. 2007; ANDERSSON, 2011). This was likewise observed in $I$. cairica, which reduced its growth through reduction in the length of branches.

The number of leaves decreased with the increase of water restriction (Figure 3 ). The same results were found by Figueirôa et al. (2004) in young Myracrodruon urundeuva plants and by Carvalho et al. (2004) in eggplant. Water stress limits not only the size, but also the number of leaves, because it reduces the number and the growth rate of the branches (TAIZ; ZEIGER, 2009).

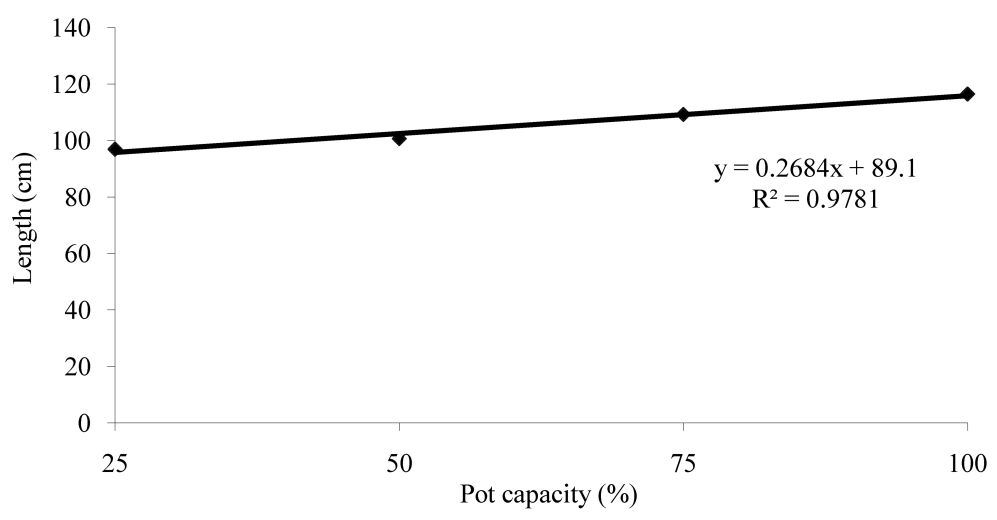

Figure 2 - Length of the longest shoot of Ipomoea cairica submitted to 25, 50, 75 and $100 \%$ of pot capacity (PC) from 30 to 60 days after transplant.

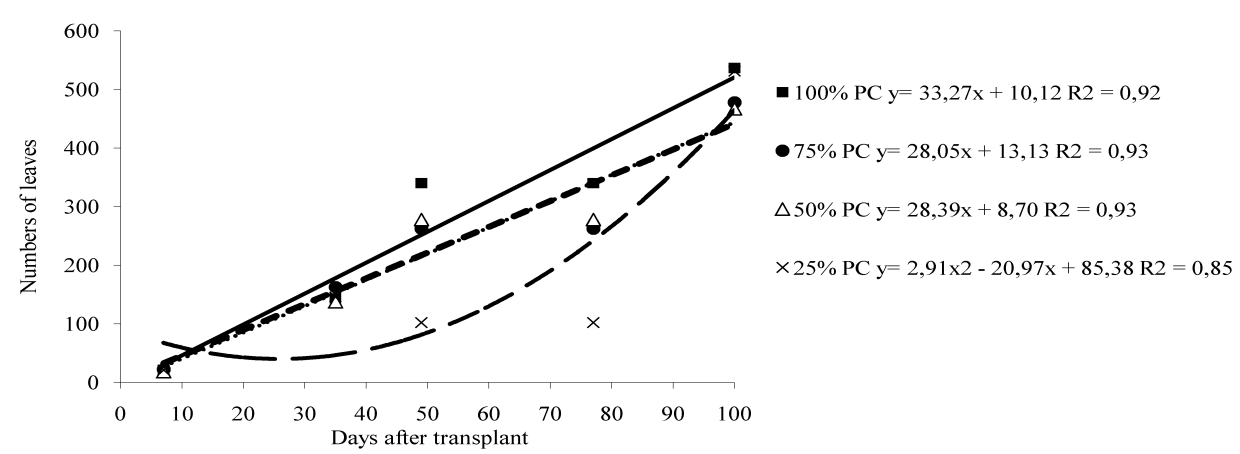

Figure 3 - Number of leaves of Ipomoea cairica submitted to 25, 50, 75 and 100\% of pot capacity (PC) during 100 days. 
Another common evolutional characteristic of plants tolerant to water stress is the production of a thick cuticle and increase of wax deposition over the leaf surface, which reduces water loss through the epidermis (cuticular transpiration) (TAIZ; ZEIGER, 2009). According to Procópio et al. (2003) I. cairica plants exhibit these important tolerance characteristics, having a thick cuticle in the adaxial part, as well as being covered with epicuticular wax. These characteristics may have contributed to drought tolerance capacity observed during this study.

Plants submitted to the lowest water level exhibited symptoms of water deficiency; however, the survival rate at the end of the 30 days of application of water deficit was $100 \%$. After returning to the normal water condition, they resume their growth processes, issuing forth new branches and leaves. The same results were found for Nerium oleander grown in a pot and submitted to low water availability, which during the stress period exhibited symptoms of deficiency, but after the restricted water deficit, the plants returned to normal appearance (LENZI et al., 2009). The same may be said for other ornamental species such as Gallardia aristada and Leucanthemum $\mathrm{x}$ superbum that resumed their growth when watered once more (ZOLLINGER et al., 2006).

There were no differences among the water treatments for fresh mass, dry mass and water mass of roots. The water level that exhibited the greatest accumulation of fresh mass of the above ground part $(92.7 \mathrm{~g})$ was that of $100 \%$ of PC, and in the period of water deficit, the plants submitted to $25 \%$ of PC obtained the lowest value $(52.8 \mathrm{~g})$. The fresh mass, dry mass and water mass variables of the above ground part (Figure 4) had linear growth throughout the experimental period. For fresh mass, dry mass, water mass of leaves, and fresh mass and water mass of stems (Figure 5) there were differences among the water deficits; the greater the moisture of the substrate, the greater the resulting masses. I. cairica plants exhibited greater accumulation of fresh mass and water mass in the stem in relation to the leaves; these masses may be related to the accumulation of compounds like amino acids and sugars arising from water restriction. Another fact that may be related to the greater accumulation of dry mass in the stem is the habit of the plant under study; since it is a climbing species, it needs to guarantee sufficient reserves to this sustaining organ.

The rate of $100 \%$ survival observed in all water regimes applied in I. cairica testify its rusticity. Other ornamental species used in landscaping as Penstemon $\mathrm{x}$ mexicali, Lavandula angustifolia (ZOLLINGER et al., 2006), and Gladiolus x grandiflorus (PEREIRA et al. 2009), do not show this survival capacity like $I$. cairica.

The results obtained in this study agree with those found in environmental conditions of habitat where $I$. cairica arises spontaneously, since this species is able to survive in locations which are quite rustic and with low water availability. Under environmental conditions where scarcity of water is a constant problem, and where water restrictions are more and more common, I. cairica clearly proves to be an excellent landscaping alternative.

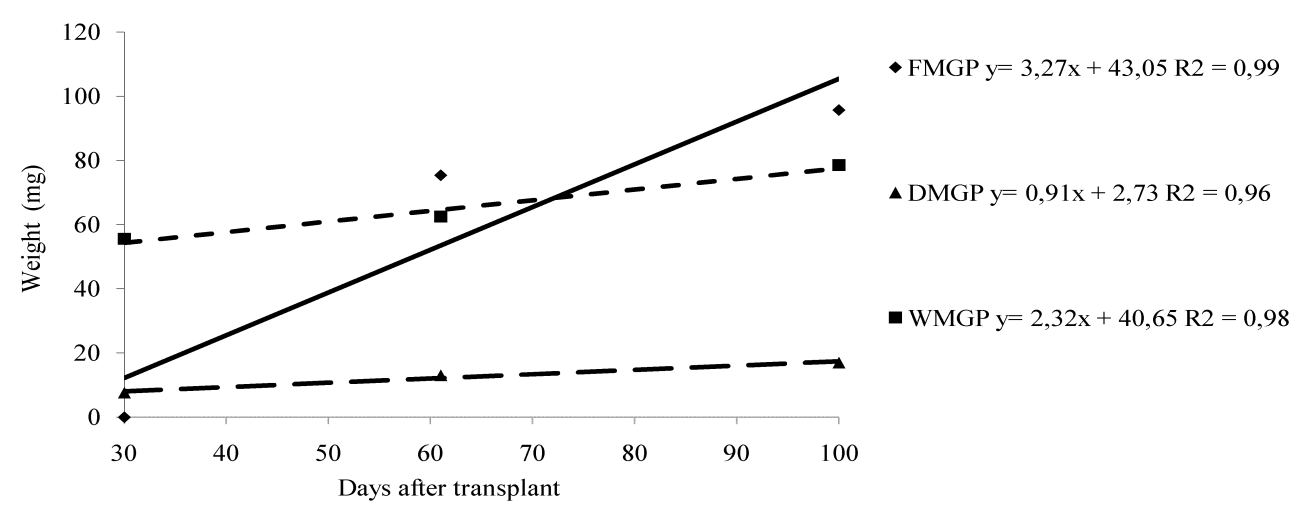

Figure 4 - Fresh mass of the above ground part (FMGP), dry mass of the above ground part (DMGP), and water mass of the above ground part (WMGP) of Ipomoea cairica submitted to 30 days of water regimes (25, 50, 75 and $100 \%$ of pot capacity) evaluated during 100 days.

Ciênc. agrotec., Lavras, v. 36, n. 3, p. 318-324, maio/jun., 2012 


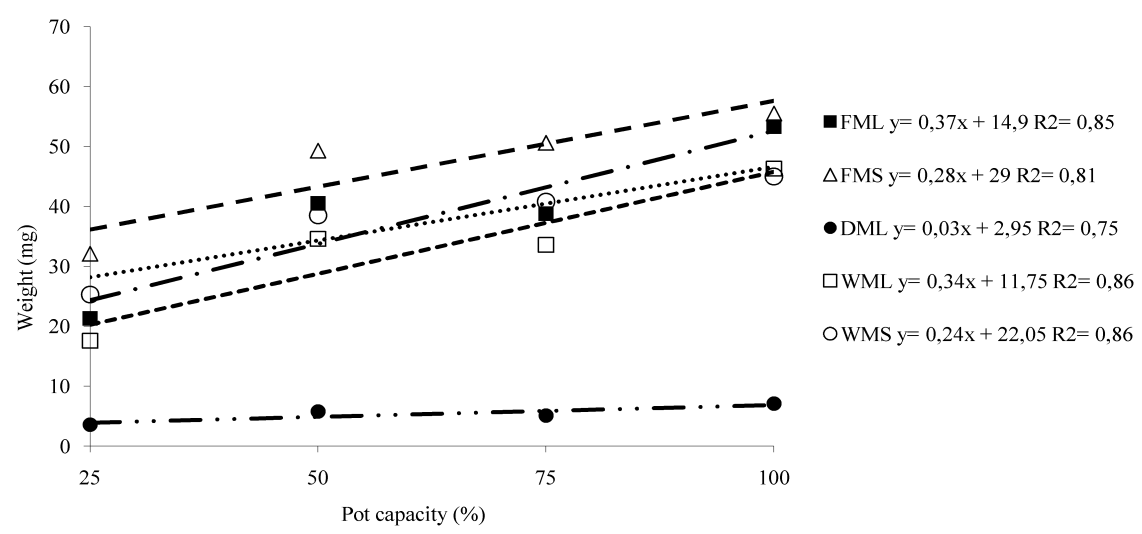

Figure 5 - Fresh mass of leaves (FML), fresh mass of stems (FMS), dry mass of leaves (DML), water mass of leaves (WML) and water mass of stems (WMS) of Ipomoea cairica in the different water deficits (25, 50, 75 and $100 \%$ of pot capacity) from 30 to 60 days after transplant.

\section{CONCLUSION}

During all regimes of water deficiency applied, there was a $100 \%$ survival rate. After reestablishment of water regime the species recovered its growth, even that was submitted to the $25 \%$ of pot capacity. It testify that $I$. cairica is resistant to low water availability.

\section{REFERENCES}

ANDERSSON, N.E. The influence of water stress and air velocity on growth of Impatiens walleriana and Petunia x hybrida. Scientia Horticulturae, Amsterdam, v.128, n.2, p.146-151, 2011.

BARROSO, C.M. et al. Considerações sobre a propagação e o uso ornamental de plantas raras ou ameaçadas de extinção no Rio Grande do Sul, Brasil. Revista Brasileira de Horticultura Ornamental, Campinas, v.13, n.2, p.91-94, 2007.

BETZEL, F.; PEZZAROSSA, B. Sustainable management of urban landscapes with wildflowers. Acta Horticulturae, Korbeek-lo, v.881, n.1, p. 213-128, 2010.

CARVALHO, L.M. et al. Disponibilidade de água no solo e crescimento de Artemísia. Horticultura Brasileira, Brasília, v.21, n.4, p. 726-730, out-dez, 2003.

CARVALHO, J.A. et al. Níveis de déficit hídrico em diferentes estádios fenológicos da cultura da berinjela (Solanum melongena L.). Engenharia Agrícola, Jaboticabal, v.24, n.2, p.320-327, 2004.
CHYLIŃSKI, W.K.; ŁUKASZEWSKA, A.J.; KUTNIK, K. Drought response of two bedding plants. Acta

Physiologiae Plantarum, Kraków, v.29, n.5, p.399-406, 2007.

CRUZIAT, P.; BODET, C. Determination des pertes en eau sobies por les différents organes de une plante soumise au desschement. Annales Agronomiques, Paris, v.25, n.4, p. 539-554, 1974.

CUQUEL, F.L. et al. Biocity Project. Acta Horticulturae, Korbeek-lo, v.813, p.95-100, 2009.

FIGUEIRÔA, J. M.; BARBOSA, D.C de A.;

SIMABUKURO, E.A. Crescimento de plantas jovens de Myracrodrum urundeuva Allemão (Anacardiaceae) sob diferentes regimes hídrico. Acta Botânica Brasílica, Feira de Santana, v.18, n.3, p.573-580. 2004.

FERREIRA, D.F. Sisvar: A computer statistical analysis system. Ciência e Agrotecnologia, Lavras, v.35, n.6, p.1039-1042, nov./dez. 2011.

FERREIRA, P.P.A.; MIOTTO, S.T.S. Sinopse das espécies de Ipomoea L. (Convolvulaceae) ocorrentes no Rio Grande do Sul, Brasil. Revista Brasileira de Biociências, v.7, n.4, p.440-453, 2009.

FRANCO, J.A. et al. Selection and nursery production of ornamental plants for landscaping and xerogardening in semi-arid environments. Journal of Horticultural Science \& Biotechnology, Ashford, v.81, n.1, p.3-17, 2006. 
HEIDEN, G; BARBIERI, R.L.; STUMPF, E.R.T.

Considerações sobre o uso de plantas ornamentais nativas. Revista Brasileira de Horticultura

Ornamental, Campinas, v.12, n.1, p.2-7, 2006.

HITCHMOUGH, J. Applying na ecological approach; the future of urban horticulture. Acta Horticulturae, Korbeek-lo, v.881, n.1, p. 193-200. 2010.

LEAL, L.; BIONDI, D. Potencial ornamental de espécies nativas. Revista Científica Eletrônica de Engenharia Florestal, Garça, v.4, n.8, p.1-16, 2006.

LENZI, A. et al. Response to water stress of some Oleander cultivars suitable for pot plant production. Scientia Horticulturae, Amsterdam, v.122, n.3, p.426$431,2009$.

LORENZI, H.; SOUZA, V.C. Plantas ornamentais no Brasil: arbustivas, herbáceas e trepadeiras. $3^{\circ}$ ed. Nova Odessa: Plantarum, 2001, 448p.

PAIVA, P. D. de O. Paisagismo: conceitos e aplicações. Lavras: Editora UFLA, 2008, 608p.

PEREIRA, J.R.D. et al. Crescimento e produção de hastes florais de gladíolo cultivado sob diferentes tensões de água no solo. Ciência e Agrotecnologia, Lavras, v. 33, p. 965-970, 2009.

PETRY, C. Adaptação de cultivares de soja a deficiência hídrica no solo. Ciência Rural, Santa Maria, v. 22, n. 1, 119-120, 1992.
PROCÓPIO, S.O. et al. Estudos anatômicos de folhas de espécies de plantas daninhas de grande ocorrência no Brasil III: Galinsoga parviflora, Crotalaria incana, Conyza bonariensis e Ipomoea cairica. Planta Daninha, Viçosa, v.21, n.1, p.1-9, 2003.

SINCLAIR, T.R.; HOLBROOK, N.M.; ZWIENIECKI, M.A. Daily transpiration rates of woody species on drying soil. Tree Physiology, Oxford, v.25, p.1469-1472, 2005.

TAIZ, L.; ZEIGER, E. Fisiologia vegetal. $4^{\mathrm{a}}$ ed. Artmed, Porto Alegre, 2009, 820p.

VAN HEERDEN, P.D.R.; LAURIE, R. Effects of prolonger restriction in water supply on phothosynthesis, shoot development and storage root yield in sweet potato. Physiologia Plantarum, Copenhagen, v.134, n.1, p.99109, set., 2008.

VIDAL, A.; ARNOUX, M. Drought tolerance process in soybean. Biologia Plantarum, Praha, v.23, n.6, p.434441, 1981.

YIN, C. et al. Adaptive responses of Populus kangdigensis to drought stress. Physiologia Plantarum, Copenhagen, v.123, p.445-451, 2005.

YOUNIS, A. et al. Potential use of wild flowers in urban landscape. Acta Horticulturae, Korbeek-lo, v.881, n.1, p.229-233, 2010.

ZOLLINGER, N. et al. Drought responses of six ornamental herbaceous perennials. Scientia Horticulturae, Amsterdam, v.109, n.3, p.267-274, 2006. 2011. 